\title{
Oxyphil Cell
}

National Cancer Institute

\section{Source}

National Cancer Institute. Oxyphil Cell. NCI Thesaurus. Code C12654.

A glandular cell with acidophilic cytoplasm that contains tightly packed mitochondria.

Oxyphil cells are found in the thyroid gland (Hurthle cells) and parathyroid gland. 